\title{
Innovation-Related Diversification and Firm Value
}

\author{
Zhao Rong ${ }^{\mathrm{a}}$ and Sheng Xiao ${ }^{\mathrm{b}}$ \\ ${ }^{a}$ Research Institute of Economics and Management, Southwestern University of Finance and \\ Economics, Chengdu, Sichuan 611130, China; Email: zrong002@fiu.edu \\ ${ }^{\mathrm{b}}$ Gore Business School, Westminster College, 1840 S 1300 E, Salt Lake City, UT 84105, USA; \\ Email: sxiao@westminstercollege.edu
}

January 15, 2014

\begin{abstract}
We examine how corporate innovations influence firms' industrial diversification decisions and how innovation-related diversification affects firm value. Our fixed effect, 2SLS and GMM models consistently show that corporate innovations lead to greater extent of diversification. The 2SLS model uses the staggered implementation of U.S. state-level R\&D tax credits as an instrumental variable for corporate innovations. We also find a firm is more likely to diversify into an industry where it has more applicable innovations. Most importantly, we find that innovation-related diversification leads to significantly higher firm value. Our results are robust to different corporate innovation measures and sample periods.
\end{abstract}

Key words: innovation; diversification; firm value

EFM Classification: 210 


\section{Introduction}

Two major views of industrial diversification lead to opposite predictions on how diversification affects firm value. On the one hand, the "agency view" argues that industrial diversification is a symptom of a firm's agency conflicts between managers and shareholders, and therefore is expected to have a negative impact on firm value. This is because managers diversify their firms in their personal interests but at the risk of lowering firm value. On the other hand, the "resource view" argues that diversification is an approach for a firm to take advantage of its excess capacity in productive factors (e.g., to optimize the allocation of excess funds through the internal capital market). By diversification, managers can help a firm better utilize its resources and consequently enhance firm value. ${ }^{1}$

Previous studies on the valuation effect of diversification mainly take the "agency view", and focus on the severity of the agency conflicts or empirical issues such as self-selection, endogeneity, and measurement problems. However, empirical evidence about the "agency view" is mixed. ${ }^{2}$ Different from these studies, this paper takes the "resource view" and proposes a new

\footnotetext{
${ }^{1}$ According to the "agency view", managers may engage in industrial diversification to increase their power, prestige and compensation, and to make themselves indispensable to the firm (Denis, Denis and Sarin, 1997), or to reduce idiosyncratic risk and to capture private benefits (May 1995; Aggarwal and Samwick, 2003). According to the "resource view", firms diversify to take advantage of their excess capacity in productive factors ("resources") such as funds (Maksimovic and Phillips, 2007), and such industrial diversification is driven by profit maximization (Maksimovic and Phillips, 2002).

${ }^{2}$ While Lang and Stulz (1994), Berger and Ofek (1995), Lins and Servaes (1999), and Lamont and Polk (2002) discover a "diversification discount", Whited (2001), Campa and Kedia (2002), and Villalonga (2004) find the "diversification discount" vanishes and sometimes even turns into a premium, after addressing measurement errors or endogeneity. Lee and Li (2012)'s quantile regression analysis reveals no diversification discount or premium.
} 
determinant of diversification's effect on firm value: corporate innovations. Specifically, a firm's innovative activities may result in innovations that are not applicable to its existing business lines. To fully capture the returns on these innovations, the firm may choose to diversify into an industry where such innovations can be utilized. We therefore hypothesize that a firm's innovations have significant and positive effects on its subsequent extent of diversification. In addition, we hypothesize that a diversifying firm is more likely to enter an industry where its innovations are more applicable. Inspired by the dynamic model of Matsusaka (2001), we regard the ongoing diversification as a "search process by which these firms try to find good matches for their organizational capabilities" (Matsusaka, 2001, p.414). Since innovative firms continuously generate innovations, it is natural to expect that these firms continuously search for good matches between their innovations and business lines through diversification. Such innovation-related diversification is expected to improve the match between a firm's innovations and its business lines. We thus hypothesize that when a diversifying firm has more applicable innovations in the industry it enters, such good match should enhance its firm value.

$3 \mathrm{M}$, one of the largest 100 firms in the world, provides a case in point. It is a very active innovator, and it has diversified into a myriad of industries. It files about 500 new patents per year, and it produces over 55,000 products in multiple industries such as aerospace, architecture, automotive, healthcare, electronics, food and beverage, and transportation, etc. As 3M states in a brochure titled A Culture of Innovation: "3M's business model is to foster organic growth by inventing new products that previously did not exist. This business model has led not only to new products, but also the creation of new industries."

\footnotetext{
${ }^{3}$ Another relevant case is given by Kazuo Suzuki (1993), Chairman of Toppan Printing Co. Ltd. in Japan, who describes how, through innovation-related diversification, his company grew rapidly into a $\$ 90$ billion business with
} 
To examine whether 3M's case is a general case that can be applied to other firms, or just a special case that only holds for 3M, we conduct a large-sample analysis of U.S. firms. We first examine whether a firm's innovations influence its extent of diversification. We measure a firm's innovations by the number of patents that the firm has accumulated, weighted by the number of citations that these patents receive. We measure a firm's extent of diversification based on the number of industries (at the 4-digit SIC level) where the firm is operating. We utilize three empirical strategies: (1) firm fixed effects models with one-year lagged innovations as the key independent variable; (2) 2SLS (two-stage-least-squares) models with the state-level R\&D tax credits as the instrument for innovations; (3) dynamic panel GMM (Generalized Method of Moments) models.

Our firm fixed effects models successfully control for the time-invariant firm-specific factors that are correlated with both innovations and diversification. Furthermore, using lagged innovations helps to mitigate the potential endogeneity issue to some degree. In these models, we find that a firm's innovations have significant and positive effects on the extent of its subsequent diversification.

However, if innovations exhibit strong autocorrelation, using lagged innovations to mitigate potential endogeneity would be less effective. To better deal with endogeneity, we resort to the 2SLS technique. Motivated by Wilson (2009), we use an exogenous policy shock, i.e., the staggered implementation of state-level $R \& D$ tax credits as the instrument for innovations. It is a valid instrument because the implementation of $R \& D$ tax credits should affect firms' innovations, but it should not directly affect firms' diversification decisions. Indeed, Wilson (2009) finds that the implementation of state-level R\&D tax credits significantly boosts firms' $R \& D$ expenditures,

19 offices overseas employing about 2200 people in the US, Europe and Asia. 
and many studies document that higher $R \& D$ expenditures are associated with more innovations (e.g, Fang, Tian and Tice, 2013). Using this exogenous policy shock, our 2SLS estimation provides evidence on the causal positive effect of a firm's innovations on its subsequent diversification.

One potential problem with the above instrument is that it only varies at the state level, so it may fail to address the possibility that the time-variant firm-specific unobservables affect both innovations and diversification. To further deal with this dynamic endogeneity issue, we follow Acemoglu et al. (2008), Wintoki, Linck and Netter (2012), Hoechle et al. (2012) and O'Connor and Rafferty (2013)'s methods and estimate dynamic panel GMM models. Doing so enables us to use firm-level "internal instruments" to tackle dynamic endogeneity. Our GMM estimation results provide further evidence on the positive causal effect of innovations on diversification.

This positive relationship between a firm's innovations and its subsequent diversification is consistent with the following two scenarios. Suppose a firm has some innovations applicable to industry A but has none applicable to industry B, and both industries are potential industries the firm may enter. Scenario (1) is that the firm subsequently diversifies into industry A, while scenario (2) is that the firm subsequently diversifies into industry B. In both scenarios, the firm's innovations are positively correlated with the extent of its subsequent diversification. If scenario (1) is true, our hypotheses will receive strong support. However, if scenario (2) is true, it will cast serious doubt on our hypotheses.

To distinguish between these two scenarios, we examine the following question: given that a firm diversifies into one of these two industries (A or B), and that its pre-entry innovations are more applicable to industry A, whether the firm is more likely to enter industry A than industry B. We measure the applicability of a firm's innovations to an industry by how well its 
accumulated patents are matched to this industry. By examining firms that diversify, we find that the applicability of a firm's innovations to a destination industry positively predicts the probability that the firm diversifies into this industry. This finding thus provides direct evidence on how technological innovations drive diversification. Silverman (1999) uses a similar method, but we improve upon his method in two aspects. First, we better control for the unobservables by estimating firm-year fixed effect models. Second, we are able to use more recent data, thanks to an updated concordance table that matches patents with industries.

After establishing the causal effect of innovations on diversification, a natural question to ask is: how does innovation-related diversification affect firm value? Our estimation results indicate that when a diversifying firm has more innovations applicable to the industry it enters, its firm value rises as a result of its innovation-related diversification.

This paper contributes to the literature in three ways. First, to the best of our knowledge, we are the first to use an exogenous policy shock (the staggered implementation of state-level R\&D tax credits) in our 2SLS estimation to establish the causal relationship between corporate innovations and industrial diversification. We are also the first to use firm-level "internal instruments" in our GMM estimation to establish such a causal relationship. ${ }^{4}$ Second, we are the first to provide evidence that innovation-related diversification enhances firm value. Third, we

\footnotetext{
${ }^{4}$ Silverman (1999) and Kaul (2012) find that a firm's technological innovation is an antecedent of diversification into relevant industries. Balasubramanian and Sivadsan (2013) find corporate innovations expand firm scope. In contrast, Miller (2004) examines 227 large US firms that undertook diversification between 1980 and 1992 and finds that less investment in $\mathrm{R} \& \mathrm{D}$ and knowledge assets predates the diversification event. However, none of these studies have addressed the endogeneity issue. Also, the samples in these studies are smaller and older than ours.
} 
introduce to the corporate finance literature a more up-to-date concordance table that maps patents to the Standard Industrial Classification (SIC) system. ${ }^{5}$

This paper is closely related to recent literature on the effects of corporate innovations on corporate financial policies. Bena and Li (2013) examine how corporate innovations affect mergers and acquisitions (M\&As). They find that firms with more innovations are more likely to be acquirers, and that the existence of technological overlaps between two firms significantly increases the likelihood of their merger pair formation. Our study differs from theirs in that industrial diversification can be regarded as a firm-to-industry match whereas an M\&A is a firmto-firm match. Therefore, industrial diversification and M\&As, though sharing some overlaps, should be distinguished from each other, and they merit separate studies. This paper complements a burgeoning literature that examines various determinants of corporate innovations ${ }^{6}$. Despite many papers that examine the determinants of innovations, how innovations affect corporate financial policies appears to remain a promising understudied research area.

This paper also complements papers that examine how diversification affects firms' innovative activities. For example, Seru (2013) finds that firms that are acquired in diversifying mergers produce both a smaller number of innovations and less novel innovations than firms that are targeted but fail to be acquired. In contrast, Cardinal and Opler (1995) find no statistically significant effect of diversification on firms' innovative efficiency among R\&D intensive firms.

\footnotetext{
${ }^{5}$ More discussions on different concordance tables are provided in section 3.

${ }^{6}$ See, for example, Aghion, Reenen and Zingales (2013), Hirshleifer, Low and Teoh (2012) and Martinsson (2010).
} 
The rest of the paper is organized as follows. Section 2 develops the hypotheses, section 3 discusses the empirical methodology, key variables and data, section 4 presents the results, and section 5 concludes.

\section{Hypothesis development}

We develop our hypotheses on the foundation of Matsusaka (2001)'s dynamic optimization model. The key assumption of his model is that a firm aims to maximize its value by choosing among specialization, diversification and liquidation. The relative firm values resulting from these three choices depend crucially on how a firm's "organizational capabilities" match its business operations. Matsusaka (2001, p.414) defines “organizational capabilities" as "firmspecific inputs to a firm's production function." We argue that corporate innovations, such as patents, fit this definition well. Matsusaka (2001) shows that when a firm's "organizational capabilities" do not match its operations very well, to maximize firm value, the firm should search for a better match in a "new" industry while keeping its operations in the "old" industry. The key reason for the firm to do so is that it is uncertain whether the firm's "organizational capabilities" would match the "new" industry, so the firm should insure against the possibility of a particularly bad outcome in the "new" industry. In this situation, the optimal strategy for the firm is to diversify.

In Matsusaka (2001)'s extended dynamic model, he permits the quality of the match between a firm's "organizational capabilities" and business segments to degrade over time. He offers one reason for such match quality erosion: the external market competition—-"other firms will eventually discover better products, production processes, and so on, eroding the profit from existing businesses." (p. 423) We argue that innovations inside a firm , as a strong internal force, are more likely to lead to match quality erosion. This is because corporate innovations are the 
most important source of "creative destruction" (Schumpeter, 1942). As Caballero and Hammour (1996, p.805) argue, "technical progress puts the economy in a state of incessant restructuring. Its productive structure must constantly adapt to innovations... Production units that embody new techniques must continually be created, while outdated units must be destroyed." We thus argue that a firm's innovations would significantly increase the probability of its match quality erosion. The probability of match quality erosion rises because as a firm innovates more, the number of innovations residing outside its current industries would increase, given that each innovation's chance of residing outside its current industries is independent. ${ }^{7}$ When the match quality erosion becomes more likely, Matsusaka (2001)'s model shows that "it pays to keep seeking new matches, even if the existing match is good" (p. 424). The above analysis leads to Hypothesis 1:

Hypothesis 1. The extent of a firm's diversification increases in its level of innovations.

Hypothesis 1 postulates a positive relationship between a firm's innovations and the extent of its subsequent diversification. Our above analysis enables us to further hypothesize that, conditional on the fact that a firm is diversifying, its original innovations would influence the direction of its diversification.

Hypothesis 2. When a diversifying firm has more innovations that are applicable to a particular industry, the likelihood of it diversifying into this particular industry increases.

When we develop Hypotheses 1 and 2, we emphasize that a poor match between a firm's technological resources and its business segments is expected to cause a firm to diversify. We can easily see that if the cause of a firm's diversification is the original mismatch between the

\footnotetext{
${ }^{7}$ This rationale is similar to Kremer (1993)'s argument that "total research output increases in proportion to population", given that "each person's chance of inventing something is independent of population."
} 
firm's technological resources and its business segments (so that some technological resources are relatively underutilized and unproductive), then when the firm diversifies into an industry that better matches its technological innovations, these unproductive technological resources will become more productive, resulting in greater firm value.

Hypothesis 3. When a firm diversifies into a "new" industry where it has more applicable innovations, its firm value will be higher.

Hypothesis 3 is consistent with not only the model in Matsusaka (2001), but also the models of Maksimovic and Philips (2002) and Gomes and Livdan (2004), where firms' diversification is regarded as a profit-maximization process and a shareholder-value-maximization process, respectively. All three models view diversification as a process to explore opportunities for productivity improvements, which results in more efficient allocation of resources. Different from Maksimovic and Philips (2002), where external demand shocks drive diversification and its valuation effects, in our paper, internal corporate innovations drive diversification and its valuation effects. Different from Gomes and Livdan (2004), who emphasize the fixed costs and synergies of diversification, we focus on the match between a firm's new technological resources and the industry which it diversifies into. We argue the quality of such match determines whether diversification is value-enhancing.

\section{Empirical methodology, key variables and data}

\subsection{Methodology}

\subsubsection{The effect of corporate innovations on the extent of diversification}

To test the relationship between a firm's original innovations and the extent of its subsequent diversification in Hypothesis 1, we set up the following fixed effect model:

$$
D I V_{i, t}=\lambda \cdot I N N O V_{i, t-1}+X_{i, t-1} \cdot \Psi+\text { Firm_dummies }+ \text { Year_dummies }+\varepsilon_{i, t},
$$


where subscripts $i$ and $t$ refer to firm and year, respectively. To mitigate the endogeneity problem, all the independent variables are lagged by one year. The variable of interest, $I N N O V_{i, t-1}$, is the innovations that firm $i$ has accumulated up to year $t-1 . I N N O V_{i, t-1}$ is one of three innovation measures, all of which will be defined in section 3.2. $X_{i, t-1}$ is a vector of one-year lagged firm characteristics as defined in the Appendix. Firm dummies and year dummies are included.

To measure a firm's extent of diversification, we use the segment count, i.e., the number of a firm's business segments at the 4-digit SIC level as our main dependent variable. Since the segment count better captures a firm's dynamics of entering and exiting industries, we use it as our main measure of a firm's extent of diversification. For robustness check, we also measure the extent of diversification by the sales-based HHI (Herfindahl-Hirschman Index), i.e., the sum of squared sales shares of all segments, where the sales share of a segment is defined as its sales over the sum of all segments' sales of the firm.

When we examine the causal impact of innovations on the extent of its diversification, we have to address endogeneity. There are two sources of endogeneity here: (1) reverse causality; and (2) common unobservables that are correlated with both innovations and diversification decisions.

We need to address reverse causality because previous studies have found that a firm's extent of diversification influences its $R \& D$ activities. On the one hand, diversification may stimulate R\&D activities. Specifically, characterized by uncertainties, R\&D activities may result in innovations in unexpected areas. With multiple business areas, a diversified firm is more likely to be able to produce and market these unexpected innovations than a firm operating in a single business area. Therefore, more diversified firms would expect higher returns from research, which would in turn lead the firm to support more research. This theory is supported by 
empirical studies that find a positive relationship between diversification and R\&D intensity (e.g, Audretsch and Feldman, 1999).

On the other hand, diversification may deter R\&D activities. Seru (2013) examines the interactions between a diversified firm's divisions and its headquarters, and explains why diversified firms may conduct less R\&D activities. Specifically, R\&D projects are characterized by great information asymmetries between researchers and outsiders. In a diversified firm, researchers in divisions may have incentives to manipulate the information that they transmit to the headquarters, especially when they face potential threats that resources may be moved away by the headquarters. Recognizing this problem, the headquarters may be reluctant to fund $R \& D$ projects in the first place. Thus, diversified firms attempting to exploit the efficiencies of a centralized resource allocation may end up with mediocre R\&D activities. Seru (2013) provides empirical evidence that diversification negatively and significantly affects innovations. In addition to reverse causality, we also need to address the possibility that some time-variant unobservables may drive both innovations and diversification.

To deal with endogeneity, we utilize the 2SLS and dynamic GMM estimation techniques. For our 2SLS estimation, we use the state-level R\&D tax credit as the instrument for innovations. States implemented R\&D tax credit policies in the U.S. in a staggered fashion between 1982 and 2006. Wilson (2009) computes the effective state-level R\&D tax credit rate for all states in the U.S. The staggered implementation of state-level R\&D tax credit policies implies that they are good candidates for effective instrumental variables. This is because Wilson (2009) finds that these tax incentives significantly stimulate $R \& D$ expenditures, and any papers find that higher R\&D expenditures are associated with more corporate innovations (e.g., Fang, Tian and Tice, 2013). Therefore, the state-level R\&D tax credit should be correlated with local firms' 
innovations, but it should not have a direct effect on local firms' diversification decisions. By instrumenting corporate innovations with the state-level $R \& D$ tax credit rate, we can effectively mitigate endogeneity. We thus estimate the following 2SLS regressions:

$$
\begin{aligned}
& \operatorname{INNOV}_{i, t-1}=\delta \cdot \operatorname{CREDIT}_{c, t-1}+X_{i, t-1} \cdot \Phi+\text { Firm_dummies }_{-} \text {Year_dummies }+\eta_{i, t-1}, \\
& \hat{\text { DIV }} V_{i, t}=\lambda \cdot I N N V_{i, t-1}+X_{i, t-1} \cdot \Psi+\text { Firm_dummies }+ \text { Year_dummies }+\varepsilon_{i, t} .
\end{aligned}
$$

As show in equation (2), the instrument is $C R E D I T_{c, t-1}$, which represents the effective $\mathrm{R} \& \mathrm{D}$ tax credit rate in state $c$ in year $t-1$ where firm $i$ is located. Its values come from Table 1 in Wilson (2007). $\Phi$ and $\Psi$ are vectors of coefficients on the vector of firm-level control variables.

One limitation of the above state-level instrumental variable is that it may fail to address common unobservables at the firm level. Suppose that there are two firms A and B in the same state, and firm A has good investment opportunities while firm B does not. Since firm A has good investment opportunities, it would respond more aggressively to the R\&D tax credit by investing more in $\mathrm{R} \& \mathrm{D}$, thereby accumulating more innovations. Meanwhile, these good investment opportunities may also induce firm A to diversify into other industries. In other words, even with the state-level instrument, firm-level unobservables may still be correlated with both a firm's innovations and its propensity to diversify. Therefore, we need to further deal with this dynamic endogeneity issue.

To control for dynamic endogeneity, we follow Acemoglu et al. (2008), Wintoki, Linck and Netter (2012), Hoechle et al. (2012) and O'Connor and Rafferty (2013), and estimate dynamic panel GMM models. Specifically, we closely follow the approach adopted by Acemoglu et al. (2008), and start by using the method developed by Anderson and Hsiao (1982). We time difference equation (1) to obtain: 


$$
\Delta D I V_{i, t}=\lambda \cdot \Delta I N N O V_{i, t-1}+\Delta X_{i, t-1} \cdot \Psi+\text { Year_dummies }+\Delta \varepsilon_{i, t}
$$

where firm dummies are removed by taking first-order difference over time. Since the original residual $\varepsilon_{i, t}$ is no longer included (assume that there is no second-order serial correlation in $\varepsilon_{i, t}$ ), $I N N O V_{i, t-2}$ is uncorrelated with $\Delta \varepsilon_{i, t}$. Therefore, it can be used as an instrument for $\Delta I N N O V_{i, t-1}$ to obtain consistent estimates.

Though the estimation of Anderson and Hsiao (1982)'s method leads to consistent estimates, there is still room for improvements in its efficiency. Under the assumption that there is no highorder serial correlation in $\varepsilon_{i, t}$, not only $I N N O V_{i, t-2}$, but all further lags of $I N N O V_{i, t-1}$ are uncorrelated with $\Delta \varepsilon_{i, t}$, therefore they can be used as additional instruments. Arellano and Bond (1991)'s difference-GMM estimation method uses all of these moment conditions and provides a more efficient estimator than Anderson and Hsiao (1982)'s estimator. We therefore estimate difference-GMM models, in addition to Anderson and Hsiao (1982)'s model. ${ }^{8}$

The above examinations, if turning out to be consistent with Hypothesis 1, would confirm that more corporate innovations cause greater extent of subsequent diversification. However, the above identification strategy fails to answer the question whether a firm's decision to enter a new

\footnotetext{
${ }^{8}$ To further improve efficiency upon Arellano and Bond (1991)'s estimator, Arellano and Bover (1995) and Blundell and Bond (1998) develop the system-GMM estimator, which uses time-differenced instruments for level equation (1). These instruments are valid only if they are orthogonal to the firm fixed effect. This is unlikely the case here since the propensity to enter a new industry is unlikely orthogonal to the firm fixed effect (Acemoglu et al. 2008). When we estimate system GMM models, the specification tests show that such models are misspecified in our context.
} 
industry is associated with the applicability of its original innovations to this industry (Hypothesis 2).

To assess whether the applicability of a firm's innovations to an industry would predict the firm's entry into the industry, we use the following empirical strategy: we examine, conditional on the fact that a firm has entered a new industry, whether the applicability of its pre-entry innovations to this industry predicts its entry into this industry rather other potential destination industries. The intuition of this strategy is as follows. For simplicity, assume that there are four industries, A, B, C and D. A firm which originally operates in industry D decides to diversify into a "new" industry (one of A, B and C). Without further information, one would predict that the probability for the firm to enter industry $\mathrm{C}$ is $1 / 3$. Now we have further information on how applicable the firm's original innovations are to these four industries. Suppose the proportions of applicable innovations among all innovations of the firm are 5\%, 5\%, 20\% and $70 \%$ for industries A, B, C and D, respectively. Based on Hypothesis 2, one should expect that the probability to enter industry $C$ should be greater than $1 / 3$, given that the proportion of innovations applicable to industry $\mathrm{C}$ is the highest among potential destination industries (A, B, and C).

Based on the above intuition, we set up a firm-year fixed-effect linear probability model to estimate the likelihood of a firm's entry into a certain industry in a given year. ${ }^{9}$ In our regression, we include only firm-years with at least one entry. Specifically, the regression is as follows:

\footnotetext{
${ }^{9}$ Originally, we try to estimate fixed-effect Logit (also called "conditional Logit") models. Unfortunately, fixedeffect Logit estimation becomes computationally infeasible in the presence of a large number of dummies (Bertrand, Luttermer and Mullainathan, 2000). Therefore, we estimate the second-best specification: the linear probability model with firm-year fixed effects.
} 


$$
\text { ENTRY }_{i, c, t}=\lambda \cdot R_{-} \operatorname{INNOV}_{i, c, t-1}+\text { Firm-year-dummies }+\varepsilon_{i, c, t}
$$

where subscripts $i, c$, and $t$ refer to firm, industry and year, respectively. The dependent variable, $E N T R Y_{i, c, t}$ is a dummy variable that equals 1 if firm $i$ enters industry $c$ in year $t$, and 0 otherwise. We are able to identify 48 different industries characterized by SIC sequence numbers. If a firm is currently operating in $N$ of these 48 industries, the number of its potential destination industries should be 48-N. The key independent variable $R_{-} I N N O V_{i, c, t-1}$ measures the extent that firm $i$ 's innovations in year $t-1$ are applicable to industry $c$. According to Hypothesis 2, the expected sign of $\lambda$ is positive. The firm-year pair dummies are included. With the inclusion of these dummies, common unobservables are well controlled for at the firm-year level. After including the firm-year pair dummies, we do not include any firm-year control variables due to multicollinearity (they are automatically dropped by Stata when we include them in regressions).

Though our method is similar to Silverman's (1999) method, our method differs from his in two major aspects. The first is the model specification. We estimate a linear probability model controlling for firm-year fixed effects, whereas Silverman (1999) does not control for firm-year fixed effects. The second is that, we use a concordance table developed and maintained by the USPTO (U.S. Patent and Trademark Office) for internal use, which is more up-to-date than the concordance tables used in previous studies. More discussions on the concordance tables are in section 3.2.

\subsubsection{The valuation effect of innovation-related diversification}

To examine whether innovation-related diversification is associated with subsequent higher firm value as Hypothesis 3 postulates, we examine whether compared with innovation-unrelated diversification, innovation-related diversification would result in higher firm value. Specifically, 
we estimate the how a firm's original innovation applicability to an industry affects its Tobin's Q, given that the firm enters this industry, in the following regression:

$$
\begin{aligned}
Q_{i, t}=\beta_{0} & +\beta_{1} \cdot R_{-} \text {INNOV }_{i, c, t-1}+\beta_{2} \cdot \text { INNOV }_{i, t-1}+\beta_{3} \cdot \text { DIV_DUM } \\
& +\beta_{5} \cdot(\text { EBIT } / \text { Sales })_{i, t-1}+\beta_{4} \cdot \ln (\text { Assets })_{i, t-1} \text { Leverage }_{i, t-1}+\beta_{7} \cdot(\text { CAPEX } / \text { Sales })_{i, t-1} \\
& +\beta_{8} \cdot \text { Sales_Growth } \\
i, t-1 & + \text { Year_dummies }+\varepsilon_{i, t}
\end{aligned},
$$

where: $Q_{i, t}$ measures firm value, and is computed as (Market value of equity + Liquidating value of preferred stock+Short-term liabilities ${ }^{-}$short term assets+book value of long-term debt)/Total assets (Chung and Pruitt 1994). $c$ is the industry that firm $i$ enters in year $t$. The key independent variable, $R \_I N N O V_{i, c, t-1}$ measures the extent that firm $i$ 's innovations in year $t-1$ are applicable to industry $c$. If the sign of the coefficient on $R_{-} I N N O V_{i, c, t-1}, \beta_{1}$ is positive, then Hypothesis 3 is supported. INNOV $V_{i, t-1}$ measures firm $i$ 's cumulative innovations up to year $t-1 . D I V_{-} D U M_{i, t-1}$ is the diversification dummy for firm $i$ in year $\mathrm{t}-1$. The other control variables are defined in the Appendix. Year dummies are included.

For regression equation (6), we narrow down our sample to firm-years where diversification occurs (i.e., at least one entry occurs). This helps us contrast the valuation effects of innovationrelated and innovation-unrelated diversification. It also helps us overcome the following endogeneity issue: unobserved firm characteristics that cause firms to diversify may also cause their values to be discounted (Campa and Kedia, 2002). Since our sample only includes diversifying firms, this endogeneity concern is mitigated.

The conventional setting in the literature on diversification discount is static, and its identification strategy is essentially to compare the firm values of focused firms versus those of diversified firms. Equation (6) deviates from the conventional setting by restricting the sample to diversifying firms. Our examination includes not only the situation where a firm was focused but 
then becomes diversified, but also the situation where a firm is already diversified but then becomes more so. The latter situation is generally ignored by the conventional setting. ${ }^{10}$

\subsection{Innovation measures}

Measures of innovations: USPTO examines patent applications with consistent criteria that ensure the novelty and relevance of an innovation. Based on the patents that a firm is granted, we generate three measures of its innovations, Patents, Qcitation-Weighted Patents and TcitationWeighted Patents. Patents refer to the cumulative number of patents awarded to a firm each year up to a given year. Following Hall, Jaffe and Trajtenberg (2005), we apply an annual depreciation rate of $15 \%$ when summing up patent counts in different years.

One limitation of Patents as a measure of innovations is that it cannot reflect the large variations in the value of individual patents. To account for this heterogeneity, we generate Qcitation-Weighted Patents and Tcitation-Weighted Patents. To compute Qcitation-Weighted Patents, we first compute the "Qcitations" of a patent. First, the number of citations that the patent receives in each year is multiplied by the weighting index from Hall, Jaffe and Trajtenberg (2001) (henceforth the "HJT weight") to correct the truncation bias. ${ }^{11}$ Then, these annual citation counts up to 2006 are summed up to get the "Qcitations" of the patent. Qcitation-Weighted Patents are the cumulative Qcitation-weighted number of patents awarded to a firm each year up to a given year. Again, an annual depreciation rate of $15 \%$ is applied.

One concern about citations is that these citations may not be comparable over years or across technology classes. To address this issue, we follow Hirshleifer, Low and Teoh (2012)

\footnotetext{
${ }^{10}$ Graham, Lemmon and Wolf (2002) is a notable exception.

${ }^{11}$ The number of citations received by a patent is truncated because citations after 2006 (the last year when NBER patent and citation data are available) are truncated. This truncation effect is biased. For example, the number of citations received by a 1987 patent is less likely to be affected by the truncation effect than that for a 1994 patent.
} 
and scale each patent's citation counts by the average citation count of all patents in the same technology class and year. For each patent, we multiply the number of scaled citations received each year up to 2006 by the HJT weights and then sum them up to get the "Tcitations" of the patent. Tcitation-Weighted Patents are the cumulative Tcitation-weighted number of patents awarded to a firm each year up to a given year.

Measures of innovation-relatedness: Based on the above three measures of innovations, we construct three proxies for $R \_I N N O V_{i, c, t-1}$ correspondingly to measure the extent that firm $i$ 's innovations in year $t$-1 are applicable/related to industry $c$. These measures are Related_Patents, Related_Qcitations and Related_Tcitations, as well as their corresponding relative measures. To compute these measures, we need to first match the patents assigned by the USPTO to the SIC system. To achieve this, we use the concordance table provided by the USPTO, titled the "OTAF (the Office of Technology Assessment and Forecast) Concordance Table" (available at www.uspto.gov). According to Hirabayashi (2003), USPTO examiners manually review the USPC (US Patent Classification) subclasses and assign them to a set of industry-based product fields based on the 1984 SIC. ${ }^{12}$ The USPTO has been maintaining and updating this concordance table between the USPC subclasses and the SIC system biannually since 1974. Specifically, the 2008 OTAF Concordance Table matches a population of 216,606 USPC subclasses with 48 industrial categories characterized by "SIC sequence numbers". The SIC sequence number (henceforth SIC_SN) system is then matched to 3-digit and sometimes 2-digit SIC codes. It covers the SIC codes between 2000 and 3900 and a single 2-digit SIC code, $13 .{ }^{13}$

\footnotetext{
${ }^{12}$ We confirmed with Mr. Jim Hirabayashi about this in our email communications.

${ }^{13}$ Though OTAF Concordance Table maps USPC subclasses into SIC-2 or SIC-3 levels instead of SIC-4 levels, it is the best U.S. patent-industry concordance table currently available to us.
} 
We will first briefly introduce Silverman's concordance table, then compare it with the OTAF Concordance Table. Silverman (1999) constructs a concordance that links the IPC (International Patent Code) system to the SIC system. He uses patents granted in Canada between 1990 and 1993 as the population. As Silverman (1999) acknowledges, his concordance table may be out of date. ${ }^{14}$ In contrast, one advantage of the 2008 OTAF Concordance Table is that it has been continuously updated for U.S. patents, better reflecting the changing situations in the U.S. and enabling us to have a larger and more up-to-date U.S. sample. The second advantage of using the OTAF Concordance Table is that it has a more refined classification of patent subclasses $(216,606$ U.S. patent subclasses) than Silverman's (about 640 IPC patent subclasses). The third advantage of using the OTAF Concordance Table is that most of the USPC subclasses are matched to a single SIC_SN. Even when a USPC subclass is matched to multiple SIC_SNs, the maximum number of SIC_SNs is only three. The major drawback of OTAF Concordance Table is that it covers only manufacturing firms, so we have to focus our research on those firms. This coverage is similar to that in many influential studies on diversification such as Maksimovic and Phillips (2002) and Schoar (2002).

Consistent with the matching process used by the USPTO to develop the OTAF Concordance Table, instead of using SIC codes, we use SIC_SNs to classify manufacturing firms into 48 industries. We determine whether a patent is related to industry $c$ (one of the 48 industries) in the following way. Each patent belongs to a USPC subclass. When a patent is under a USPC subclass that is assigned only to industry $c$, it is counted as one patent related to industry $c$. When a patent is in a USPC subclass that is matched to more than one industry, the

\footnotetext{
${ }^{14}$ Yale Technology Concordance (YTC) extends Silverman's concordance to all Canadian patents up to 1995. However, compared with the 2008 OTAF Concordance Table we use in the paper, it still appears to be out of date.
} 
patent is evenly matched to these industries. For example, suppose that a patent is assigned to three industries, one of them being industry $c$. Then, 1/3 of this patent is counted as being related to industry $c$. We then aggregate the number of patents related to industry $c$ each year, and sum them up till year $t-1$ by applying an annual depreciation rate of $15 \%$ to get the first measure of innovation-relatedness to industry $c$, Related Patents. To address the heterogeneity of the value of patents, we derive two additional measures of innovation-relatedness, Related Qcitations and Related Tcitations. These two are similar to Related Patents. The only difference is that each patent related to industry $c$ is weighted by its Qcitations and Tcitations, respectively, before we sum them up.

Next, based on Related_Patents, Related_Qcitations and Related_Tcitations, we derive three relative measures of innovation-relatedness-to-industry-c. Related Patents\% is defined as the proportion of Related Patents to industry $c$ among a firm's Patents, Related Qcitations\% is defined as the proportion of Related Qcitation-Weighted Patents among a firm's QcitationWeighted Patents and Related Tcitations $\%$ is defined as the proportion of Related TcitationWeighted Patents among a firm's Tcitation-Weighted Patents, respectively.

In summary, we construct three pairs of measures for firm $i$ 's innovation-relatedness to industry $c$ in year $t-1, R \_I N N O V_{i, c, t-1 .}$

\subsection{Data}

The data come from two major sources. Our patent data are from the NBER (National Bureau of Economic Research) Patent Database. ${ }^{15}$ This database covers more than 3.2 million

\footnotetext{
${ }^{15}$ The patent data are collected, maintained, and provided by NBER Patent Data Project. All data files that we use, along with documentation, are available at https://sites.google.com/site/patentdataproject.
} 
patents and 23.6 million patent citations in the U.S. between 1976 and 2006. Our firm-level and segment-level financial data are from the Compustat annual company and segment files.

Similar to Seru (2013), we choose the sample period 1980-1997 for two reasons. First, the latest records in the NBER patent and citations database are for 2006. There is a well-known problem of truncated citations received by patents, especially for those patents filed close to 2006. We set our cutoff year to 1997 to alleviate this truncation bias. Seru (2013, p.12) also indicates that over 1980-1997, "information on citations received by patents is reliably available." Second, according to Seru (2013) and Hoechle et al. (2012), the reporting of segment level information underwent a change in 1998. Starting from 1998, firms were required to report "operation segments" instead of "industry segments". This change makes the comparison of segments across time periods difficult. To ensure that the definitions of segments are timeconsistent, we use data prior to $1998 .^{16}$

To form our data sample, we start with all firms included in Compustat industry segment files for 1980-1997. We then narrow our sample by excluding the following firms: (1) those in the financial industry or government sector (i.e., with segments in the 1-digit SIC code of 6 (financial firms) or 9 (government firms)); (2) those with invalid primary 4-digit SIC code ("sics1"); (3) those with incomplete or invalid information on segment sales; (4) those with the sum of the segment sales not within $5 \%$ of the total net sales; (5) those with sales less than $\$ 1$ million. The above data screening criteria are similar to those in Seru (2013). We then merge the resulting sample with the 2006 NBER Patent Database.

\footnotetext{
${ }^{16}$ Our robustness check shows that even when we extend the sample period to 2004, our main results still hold. Though the last year when the NBER patent data are available is 2006, due to truncation bias, the last year when reliable citation data are available is 2004, according to Hall, Jaffe and Trajtenberg (2001).
} 
Table 1 (panel A) reports the summary statistics of firm characteristics. The variable definitions are in the Appendix. All variables are lagged for one year (as independent variables in regressions) except for contemporaneous variables measuring the extent of diversification (as dependent variables in regressions). We winsorize all financial variables at top and bottom $1 \%$ levels to mitigate the undue influence of outliers. Panel B reports the summary statistics for diversified firms (firm-years with multiple segments) and focused firms (firm-years with one segment), respectively. Comparatively, diversified firms are larger, and have more innovations.

\section{Results}

\subsection{Ex-ante diversification effects}

In this section, we report multivariate analysis results on the effect of a firm's innovations on the extent of its subsequent diversification (Hypothesis 1) and diversification direction (Hypothesis 2).

\subsubsection{How do corporate innovations affect the extent of industrial diversification?}

We first regress the extent of a firm's diversification on its innovations in the previous year as in regression equation (1). In Table 2, we use the segment count to measure the extent of diversification. Column (1) to (3) of panel A present the estimation results by using three different measures of innovations, $\ln (1+$ Patents $), \ln (1+$ Qcitation-Weighted Patents $)$ and $\ln (1+$ Tcitation-Weighted Patents $)$, respectively. The estimation results indicate that, the effect of innovations is significantly positive after controlling for other influential factors, as well as firm and year fixed effects.

To deal with the endogeneity issue, columns (4) to (6) of panel A repeat the regressions of columns (1) to (3) by using the state R\&D tax credit rate as the instrument for innovations. We first check the validity and quality of this instrument. We conduct endogeneity tests (Durbin-Wu- 
Hausman Chi-square tests) to examine whether the OLS estimates are different from the IV estimates. The null hypothesis of the tests is that there are no significant differences between these two estimates. The test results reject the null hypothesis and indicate that the IV estimates are significantly different from the OLS estimates, implying serious endogeneity in OLS models and confirming the necessity of IV estimation. Then, we perform the weak IV test to determine whether the instrument is sufficiently correlated with the endogenous regressor. In all three cases, the Cragg-Donald-Wald F-statistics exceed the critical value at the $10 \%$ significance level (Stock and Yogo, 2005), confirming that our instrument is strong. Our 2SLS estimation results show that more innovations are associated with higher segment counts in the subsequent year. Using the instrumental variable, the estimated coefficients on innovations actually become larger, providing even stronger support to Hypothesis 1.

As discussed before, the above state-level instrument may fail to address common unobservables at the firm level. Therefore we turn to dynamic GMM models. In columns (1) to (3) of panel B, we repeat the regressions of columns (1) to (3) in panel A by adopting Anderson and Hsiao's (1981) dynamic panel estimation method as in equation (4). We use $I N N O V_{i, t-4}$ as the instrument for $\triangle I N N O V_{i, t-1}$. Due to the high degree of autocorrelation of INNOV, we find that we have to lag INNOV at least 4 periods so that the instrument is uncorrelated with $\Delta \varepsilon_{i, t}$. The sample sizes in panel B are smaller than those in panel A. This is because when we estimate the dynamic panel models with 4-year lags, firms with observations of fewer than 4 years are 
automatically dropped out ${ }^{17}$. The estimated coefficient on lagged innovations remains significantly positive. For brevity, we suppress the coefficients on the control variables.

Columns (4) to (6) of panel B report the difference-GMM estimation results. Again, we use $I N N O V_{i, t-4}$ as the instrument for $\triangle I N N O V_{i, t-1} . \mathrm{AR}(4)$ is the test for fourth-order autocorrelation in $\Delta \varepsilon_{i, t}$ with the null hypothesis of no serial correlation. Our $\mathrm{AR}(4)$ test results show that there are no significant (or marginally significant) fourth-order autocorrelations of $\Delta \varepsilon_{i, t}$. To test the validity of our instruments, we further conduct the Hansen test of overidentification. The null hypothesis of the Hansen test is that all instruments are valid. Our Hansen test cannot reject the null. Therefore, our GMM regressions appear to be well-specified, and they show that corporate innovations in the previous year cause significantly greater extent of diversification this year.

In conclusion, our fixed-effect OLS, 2SLS, Anderson-Hsiao, and GMM estimation results all consistently show that a firm's innovations cause significantly greater extent of its subsequent diversification, as predicted by Hypothesis 1. This relationship is robust to different measures of innovations.

For robustness checks, we also use the diversification dummy and the sales-based HHI to measure the extent of diversification, respectively. We believe that the segment count captures the dynamics of a firm's diversification the best, whereas the diversification dummy only captures a firm's change from 1 industry to 2 or more industries, and HHI may understate the effect of a new entry because the sales of the newly entered industry is generally smaller than those of a firm's original industries. Correspondingly, when we use either the diversification

\footnotetext{
${ }^{17}$ In fact, we find that for a firm with fewer than 8 consecutive years of observations, the high autocorrelation of $I N N O V$ and the small number of observations for the firm cause $I N N O V_{t-4}$ to be significantly correlated with $\Delta \varepsilon_{i, t}$, so we further require a firm to have at least 8 consecutive years of observations to be included in the GMM sample .
} 
dummy or HHI as the dependent variable, the estimated effects of innovations on the extent of diversification are still positive but they are not as strong as in the case when we use the segment count. For brevity, we do not report the results here, but they are available upon request.

\subsubsection{How does innovation-relatedness affect the direction of diversification?}

We have established the causal relationship from a firm's innovations to its subsequent extent of diversification. In this section, we will examine whether the destination industry that a firm enters can be explained by the applicability of the firm's innovations to this industry. Specifically, we estimate a fixed-effect linear probability model as in regression equation (5).

An entry into one of the 48 manufacturing industries is confirmed if the firm reports at least one business line within this industry in the year, but it did not report so in any of the previous three years. We end up with 2,411 entry counts within the sample period, involving 2,165 firmyears due to the existence of firm-years with multiple entries. ${ }^{18}$ There are a maximum number of $2,165 * 48=103,920$ potential destination industries. However, if a firm is already operating in one or more industries, the number of its potential destination industries would be fewer than 48 . By excluding those industries where the firm has already been operating in at least one of the previous three years, we end up with 99,815 observations.

Panel A of Table 3 presents the summary statistics of the sample. To compare the differences between firm-year-industries where the firm does not enter the industry in the year and those where the firm does, we divide the sample into two groups and report their respective summary characteristics. On average, those firm-year-industries where the firm enters the

\footnotetext{
${ }^{18}$ Among these 2,165 firm-years, there are 1,954 with only one entry, 182 with two entries, 24 with three entries, 4 with four entries, and 1 with five entries.
} 
industry in the year have more related innovations as well as higher proportions of related innovations (henceforth "related innovation\%"), no matter which proxy of innovations is used.

Columns (1) to (3) of panel B present the estimation results for the full sample by using three pairs of measures to proxy $R_{-} I N N O V_{i, c, t-1}$, respectively. In each case, both the effects of related-innovations and "related-innovations\%" are positive and significant at the $1 \%$ level. The results indicate that the more related a firm's innovations are to an industry, the more likely the firm will diversify into the industry. These results strongly support Hypothesis 2 and show that a firm's innovations are indeed an important driving force of the direction of its diversification.

In the sample that we use to generate columns (1) to (3) of Table 3, when there is no patent for a firm-year, we set the value of "related innovations\%" to 0. Alternatively, we can examine the subsample of firm-years with Patents greater than zero. Using this subsample, we rerun the regressions of columns (1) to (3) and report the results in columns (4) to (6). The positive effects of related-innovations and "related-innovations\%" persist.

It is possible that firm-years with multiple entries have characteristics different from those with only one entry. Panel $\mathrm{C}$ repeats the regressions of panel B by excluding firm-years with multiple entries. The major results continue to hold.

\subsection{Ex-post valuation effects}

So far, we have established the ex-ante effects of a firm's innovations on the extent of its subsequent diversification and the direction of diversification, respectively. We now investigate whether and how innovation-related diversification affects firm value (Hypothesis 3). We start with the 2,165 firm-years with at least one entry, and end up with 1,601 valid firm-years when

additional control variables are included. Panel A of Table 4 presents the summary statistics of these firm-years. We divide the sample into two subsamples by whether Tobin's Q is higher or 
lower than the sample median. On average, firm-years with higher Tobin's Q have more innovations and higher "related-innovations\%", no matter which proxy of innovations is used.

Columns (1) to (3) of panel B present the estimation results of equation (6) with the full sample. We use Related Patents\%, Related Qcitations\% and Related Tcitations\% to measure the degree of relatedness of a firm's pre-entry innovations to the industry it enters, respectively. For firm-years with multiple entries, we use the mean of "related-innovations\%" among these entered industries to measure the average innovation-relatedness. The estimation results are consistent with Hypothesis 3, as firm value is significantly higher when it diversifies into a "new" industry where its innovations are more applicable. The coefficients of control variables have the expected signs. Most notably, the effect of the diversification dummy is significantly negative in all models, consistent with Lang and Stulz (1994)'s main findings on the "diversification discount."

In columns (4) to (6) of panel B we examine the subsample of firm-years with Patents greater than zero and rerun the regressions of columns (1) to (3). The positive effect of "relatedinnovations\%" persists. Recall that for firm-years with multiple entries, we use the mean of "related-innovations\%" among these entries as the measure of innovation-relatedness. This treatment might be problematic if the mean does not well represent the innovation-relatedness in such circumstances. Therefore, as a robustness check, in panel $\mathrm{C}$ we delete firm-years with multiple entries and rerun the regressions of panel B. The major results continue to hold.

\section{Conclusions}

Despite the long tradition of the "agency view" about the motivation and the valuation effects of industrial diversification, the related empirical evidence is mixed. Such mixed evidence highlights the need for an alternative view to complement the "agency view". This 
paper examines diversification from an alternative view, the "resource view", which regards diversification as a dynamic process through which a firm continuously searches for good match between its resources and business.

In this paper, we focus on one important driving force of diversification that has been understudied: corporate innovations. We hypothesize that corporate innovations inside a firm create mismatch between the firm's technological resources and its current business. To achieve better match, the firm would diversify into a "new" industry. Such innovation-related diversification is expected to improve the match between the firm's technological resources and its business. As a result, its firm value is expected to rise. Consistent with the above hypotheses, we find that corporate innovations cause significantly more diversification. Furthermore, when a firm diversifies into an industry where it has more applicable innovations, its firm value significantly rises. These results are robust to various estimation techniques and measures of corporate innovations.

Our results show that the driving forces of diversification and its valuation effect are not limited to the synergies in internal capital markets (Maksimovic and Phillips, 2007) and internal labor markets (Tate and Yang, 2012). The synergies in internal technological resource markets are an important driving force that has received insufficient attention. As corporate innovations expand the boundaries of the internal technological resource markets, firms diversify into "new" industries where they can fully utilize their newly developed technological resources. Such innovation-related diversification significantly boosts firm value. 


\section{References}

Acemoglu, D., Johnson, S., Robinson, J. A., Yared, P., 2008. Income and democracy. American Economic Review 98, 808-842.

Aggarwal, R. K., Samwick, A. A., 2003. Why do managers diversify their firms? Agency reconsidered. Journal of Finance 58, 71-118.

Aghion, P., Reenen, J. V., Zingales, L., 2013. Innovation and institutional ownership. American Economic Review 103, 277-304.

Anderson, T. W., Hsiao, C., 1981. Estimation of dynamic models with error components. Journal of the American Statistical Association 76, 598-606.

Arellano, M., Bond, S. R., 1991. Some tests of specification for panel data: Monte Carlo evidence and an application to employment equations. Review of Economic Studies 58, 277-297.

Arellano, M., Bover, O., 1995. Another look at the instrumental-variable estimation of error-components models. Journal of Econometrics 68, 29-52.

Audretsch, D. B., Feldman, M. P., 1999. Innovation in cities: science-based diversity, specialization and localized competition. European Economic Review 43, 409-429.

Balasubramanian, N., Sivadasan, J., 2011. What happens when firms patent? New evidence from US economic census data. Review of Economics and Statistics 93, 126-146.

Bena, J., Li, K., 2013. Corporate innovations and mergers and acquisitions. Journal of Finance, forthcoming.

Berger, P. G., Ofek, E., 1995. Diversification's effect on firm value. Journal of Financial Economics 37, 39-65.

Bertrand, M., Luttermer, E. F. P., Mullainathan, S., 2000. Network effects and welfare cultures. Quarterly Journal of Economics 115, 1019-1055.

Blundell, R., Bond, S., 1998. Initial conditions and moment restrictions in dynamic panel data models. Journal of Econometrics 87, 115-143.

Caballero, R. J., Hammour, M. L., 1996. On the timing and efficiency of creative destruction. Quarterly Journal of Economics 111, 805-852.

Campa, J. M., Kedia, A., 2002. Explaining the diversification discount. Journal of Finance 57, $1731-1762$.

Cardinal, L. B., Opler, T. C., 1995. Corporate diversification and innovative efficiency: an empirical study. Journal of Accounting and Economics 19, 365-381.

Chung, K. H., Pruitt, S. W., 1994. A simple approximation of Tobin's q. Financial Management 23, 70-74.

Denis, D. J., Denis, D. K., Atulya, S., 1997. Agency problems, equity ownership, and corporate diversification. Journal of Finance 52, 135-160.

Fang, V., Tian, X., Tice, S., 2013. Does stock liquidity enhance or impede firm innovation? Journal of Finance, forthcoming.

Gomes, J., Livdan, D., 2004. Optimal diversification: reconciling theory and evidence. Journal of Finance 59, 507-535.

Graham, J. R., Lemmon, M. L., Wolf, J. G., 2002. Does corporate diversification destroy value? Journal of Finance 57, 695-720.

Hall, B., Jaffe, A., Trajtenberg, M., 2001. The NBER patent citations data file: Lessons, insights and methodological tools. NBER Working Paper No. 8498.

Hall, B., Jaffe, A., Trajtenberg, M., 2005. Market value and patent citations. RAND Journal of Economics 36, 16-38.

Hirshleifer, D. A., Teoh, S. H., Low, A., 2012. Are overconfident CEOs better innovators? Journal of Finance 67, 1457-1498.

Hirabayashi, J., 2003. Revisiting the USPTO concordance between the U.S. patent classification and the Standard Industrial Classification systems. Working paper.

Hoechle, D., Schmid, M., Walter, I., Yermack, D., 2012. How much of the diversification discount 
can be explained by poor corporate governance? Journal of Financial Economics 103, 41-60.

Kaul, A., 2012. Technology and corporate scope: firm and rival innovation as antecedents of corporate transactions. Strategic Management Journal 33, 347-367.

Kremer, M., 1993. Population growth and technological change: 1,000,000 B.C. to 1990. Quarterly Journal of Economics 108, 681-716.

Lamont, O. A., Polk, C., 2002. Does diversification destroy value? Evidence from the industry shocks. Journal of Financial Economics 63, 51-77.

Lang, L. H. P., Stulz, R. M., 1994. Tobin's q, corporate diversification, and firm performance. Journal of Political Economy 102, 1248-1280.

Lee, B. S., Li, M. L., 2012. Diversification and risk-adjusted performance: A quantile regression approach. Journal of Banking and Finance 36, 2157-2173.

Lins, K., Servaes, H., 1999. International evidence on the value of corporate diversification. Journal of Finance 54, 2215-2240.

Maksimovic, V., Phillips, G. M., 2002. Do conglomerate firms allocate resources inefficiently? Evidence from plant-level data. Journal of Finance 57, 721-767.

Maksimovic, V., Phillips, G. M., 2007. Conglomerate firms and internal capital markets. In Eckbo, B. E. (Eds.), Handbook of Corporate Finance, Volume 1. Elsevier/North-Holland, Amsterdam.

Martinsson, G., 2010. Equity financing and innovation: Is Europe different from the United States? Journal of Banking and Finance 34, 1215-1224.

Matsusaka, J. G., 2001. Corporate diversification, value maximization, and organizational capabilities. Journal of Business 74, 409-431.

May, D. O., 1995. Do managerial motives influence firm risk reduction strategies? Journal of Finance 50, 1291-1308.

Miller, D. J. 2004. Firm's technological resources and the performance effects of diversification: a longitudinal study. Strategic Management Journal 25, 1097-1119.

O'Connor, M., Rafferty, M., 2013. Corporate governance and innovation. Journal of Financial and Quantitative Analysis, forthcoming.

Schoar, A., 2002. Effects of corporate diversification on productivity. Journal of Finance 57, 2379-2403.

Schumpeter, J. A., 1942. Capitalism, Socialism, and Democracy. Harper and Brothers, New York.

Seru, A., 2013. Firm boundaries matter: evidence from conglomerates and R\&D activity. Journal of Financial Economics, forthcoming.

Silverman, B. S., 1999. Technological resources and the direction of corporate diversification: Toward an integration of the resource-based view and transaction cost economics. Management Science 45, 1109-1124.

Stock, J. H., Yogo, M., 2005. Testing for Weak Instruments in Linear IV Regression. In Andrews, D. W. K, Stock, J. H. (Eds.) Identification and Inference for Econometric Models: Essays in Honor of Thomas Rothenberg, Cambridge University Press, Cambridge.

Suzuki, K., 1993. Toppan printing: successful diversification through technology. Long Range Planning 26, 42-52.

Tate, G., Yang, L., 2012. The bright side of corporate diversification: evidence from internal labor markets. University of Maryland working paper.

Villalonga, B., 2004. Diversification discount or premium? New evidence from the Business Information Tracking series. Journal of Finance 59, 479-506.

Whited, T., 2001. Is it inefficient investment that causes the diversification discount? Journal of Finance $56,1667-1692$.

Wilson, D., 2007. Beggar thy Neighbor? The in-state, out-of-state, and aggregate effects of R\&D tax credits. Federal Reserve Bank of San Francisco working paper 2005-08.

Wilson, D., 2009. The in-state, out-of-state, and aggregate effects of R\&D tax credits. Review of Economics and Statistics 91, 431-436.

Wintoki, M. B., Linck, J. S., Netter, J. M., 2012. Endogeneity and the dynamics of internal corporate governance. Journal of Financial Economics 105, 581-606. 
Table 1

Summary statistics of firm characteristics.

Panel A. Full sample

\begin{tabular}{llllll}
\hline Variable & Mean & Median & Std. Dev. & Q1 & Q3 \\
\hline Segment count & 1.58 & 1.00 & 1.06 & 1.00 & 2.00 \\
Diversification dummy & 0.31 & 0.00 & 0.46 & 0.00 & 1.00 \\
Sales-based segment HHI & 0.86 & 1.00 & 0.23 & 0.71 & 1.00 \\
Patents & 43.41 & 2.00 & 237.50 & 0.00 & 9.99 \\
Qcitation-weighted patents & 701.11 & 25.89 & 4683.05 & 0.00 & 164.47 \\
Tcitation-weighted patents & 52.80 & 2.10 & 298.80 & 0.00 & 12.81 \\
Sales (Million USD) & 760.06 & 86.70 & 2866.42 & 19.58 & 406.84 \\
Assets (Million USD) & 969.14 & 91.07 & 3743.90 & 24.53 & 421.89 \\
EBIT/Sales & -0.04 & 0.07 & 0.88 & 0.02 & 0.12 \\
CAPEX/Sales & 0.10 & 0.05 & 0.91 & 0.03 & 0.09 \\
Leverage & 0.47 & 0.48 & 0.21 & 0.31 & 0.62 \\
\hline Observations & 36314 & & & & \\
\hline
\end{tabular}

Panel B. Diversified firms versus focused firms

\begin{tabular}{lllllll}
\hline & \multicolumn{3}{c}{ Diversified firms } & $(N=11349)$ & \multicolumn{3}{c}{ Focused firms $(N=24965)$} \\
Variable & Mean & Median & Std. Dev. & Mean & Median & Std. Dev. \\
\hline Segment count & 2.85 & 3.00 & 1.10 & 1.00 & 1.00 & 0.00 \\
Diversification dummy & 1.00 & 1.00 & 0.00 & 0.00 & 0.00 & 0.00 \\
Sales-based segment HHI & 0.55 & 0.53 & 0.18 & 1.00 & 1.00 & 0.00 \\
Patents & 82.25 & 4.68 & 303.17 & 25.75 & 1.44 & 198.18 \\
Qcitation-weighted patents & 1068.07 & 51.71 & 4419.38 & 534.30 & 18.76 & 4788.91 \\
Tcitation-weighted patents & 92.29 & 4.68 & 349.74 & 34.84 & 1.48 & 270.63 \\
Sales (Million USD) & 1247.82 & 260.91 & 3387.68 & 538.33 & 54.79 & 2564.67 \\
Assets (Million USD) & 1539.41 & 276.93 & 3837.05 & 709.91 & 59.26 & 3671.69 \\
EBIT/Sales & 0.06 & 0.07 & 0.21 & -0.08 & 0.07 & 1.05 \\
CAPEX/Sales & 0.08 & 0.05 & 0.12 & 0.11 & 0.05 & 1.09 \\
Leverage & 0.53 & 0.54 & 0.18 & 0.45 & 0.44 & 0.22 \\
\hline
\end{tabular}

This table presents the summary statistics of firm characteristics. To form our data sample, we start with all firms listed on the Compustat annual company and segment files for 1980-1997. We then narrow our sample by excluding the following firms: (1) those with segments in the 1-digit SIC code of 6 (financial firms) or 9 (government firms); (2) those with invalid primary 4-digit SIC code ("sics1"); (3) those with incomplete or invalid information on segment sales; (4) those with the sum of the segment sales not within 5\% of the total net sales; (5) those with sales less than $\$ 1$ million. We then merge the resulting subset with the 2006 NBER Patent Database. Panel A reports the summary statistics of firm characteristics. The variable description is presented in the Appendix. All variables are lagged for one year except that variables related to the extent of diversification are contemporaneous. In the estimations, we winsorize all financial variables at $1 \%$ level; we report their summary statistics accordingly. For comparison, panel B reports the summary statistics of diversified firms and focused firms, respectively. 
Table 2

The effect of innovations on the extent of diversification.

Panel A. Fixed-effects estimation and 2SLS estimation results

\begin{tabular}{|c|c|c|c|c|c|c|}
\hline \multirow[b]{3}{*}{ Innovations are measured by } & \multicolumn{6}{|c|}{ Dependent variable: Segment count } \\
\hline & \multicolumn{3}{|c|}{ Fixed Effect Model } & \multicolumn{3}{|c|}{ 2SLS Model } \\
\hline & $\begin{array}{l}\text { Patents } \\
\text { (1) }\end{array}$ & $\begin{array}{l}\text { Qcitationss } \\
\text { (2) }\end{array}$ & $\begin{array}{l}\text { Tcitationss } \\
\text { (3) }\end{array}$ & $\begin{array}{c}\text { Patents } \\
\text { (4) }\end{array}$ & $\begin{array}{l}\text { Qcitations } \\
\text { (5) }\end{array}$ & $\begin{array}{l}\text { Tcitations } \\
(6)\end{array}$ \\
\hline $\ln (1+$ Innovations $)$ & $\begin{array}{c}0.031^{* *} \\
(0.013)\end{array}$ & $\begin{array}{c}0.017 * * * \\
(0.001)\end{array}$ & $\begin{array}{l}0.029 * * * \\
(0.007)\end{array}$ & $\begin{array}{r}0.473^{* *} \\
(0.002)\end{array}$ & $\begin{array}{l}0.412 * * * \\
(0.006)\end{array}$ & $\begin{array}{c}0.482 * * * \\
(0.002)\end{array}$ \\
\hline $\ln$ (Assets) & $\begin{array}{c}0.141 * * * \\
(0.000)\end{array}$ & $\begin{array}{c}0.141 * * * \\
(0.000)\end{array}$ & $\begin{array}{c}0.140 * * * \\
(0.000)\end{array}$ & $\begin{array}{c}0.007 \\
(0.881)\end{array}$ & $\begin{array}{l}-0.076 \\
(0.363)\end{array}$ & $\begin{array}{l}-0.010 \\
(0.844)\end{array}$ \\
\hline EBIT/Sales & $\begin{array}{c}-0.050^{* * * *} \\
(0.000)\end{array}$ & $\begin{array}{c}-0.048 * * * \\
(0.000)\end{array}$ & $\begin{array}{c}-0.050 * * * \\
(0.000)\end{array}$ & $\begin{array}{l}-0.006 \\
(0.763)\end{array}$ & $\begin{array}{c}0.062 \\
(0.173)\end{array}$ & $\begin{array}{c}0.003 \\
(0.910)\end{array}$ \\
\hline CAPEX/Sales & $\begin{array}{c}-0.244 * * * \\
(0.000)\end{array}$ & $\begin{array}{l}-0.244 * * * \\
(0.000)\end{array}$ & $\begin{array}{c}-0.244 * * * \\
(0.000)\end{array}$ & $\begin{array}{l}-0.045 \\
(0.555)\end{array}$ & $\begin{array}{c}0.077 \\
(0.552)\end{array}$ & $\begin{array}{l}-0.038 \\
(0.635)\end{array}$ \\
\hline Leverage & $\begin{array}{l}-0.003 \\
(0.922)\end{array}$ & $\begin{array}{l}-0.001 \\
(0.986)\end{array}$ & $\begin{array}{l}-0.003 \\
(0.922)\end{array}$ & $\begin{array}{l}-0.000 \\
(0.997)\end{array}$ & $\begin{array}{l}0.070^{*} \\
(0.068)\end{array}$ & $\begin{array}{l}-0.000 \\
(0.986)\end{array}$ \\
\hline Firm dummy & Yes & Yes & Yes & Yes & Yes & Yes \\
\hline Year dummy & Yes & Yes & Yes & Yes & Yes & Yes \\
\hline Observations & 36314 & 36314 & 36314 & 36132 & 36132 & 36132 \\
\hline Adjusted R-squared & 0.068 & 0.068 & 0.068 & 0.021 & 0.021 & 0.021 \\
\hline $\begin{array}{l}\text { Endogeneity test } \\
\text { Durbin-Wu-Hausman P-value }\end{array}$ & & & & 0.001 & 0.001 & 0.001 \\
\hline Cragg-Donald Wald F statistic & & & & 63.04 & 18.95 & 47.72 \\
\hline $10 \%$ Critical value by Stock and & go (2005) & & & 16.38 & 16.38 & 16.38 \\
\hline
\end{tabular}

Panel B. Anderson-Hsiao estimation and GMM estimation results

\begin{tabular}{|c|c|c|c|c|c|c|}
\hline \multirow[b]{3}{*}{ Innovations are measured by } & \multicolumn{6}{|c|}{ Dependent variable: Segment count } \\
\hline & \multicolumn{3}{|c|}{ Anderson-Hsiao Model } & \multicolumn{3}{|c|}{ GMM Model } \\
\hline & $\begin{array}{l}\text { Patents } \\
\text { (1) }\end{array}$ & $\begin{array}{l}\text { Qcitations } \\
\text { (2) }\end{array}$ & $\begin{array}{c}\text { Tcitations } \\
\text { (3) }\end{array}$ & $\begin{array}{l}\text { Patents } \\
\text { (4) }\end{array}$ & $\begin{array}{l}\text { Qcitations } \\
\text { (5) }\end{array}$ & $\begin{array}{c}\text { Tcitations } \\
\text { (6) }\end{array}$ \\
\hline $\ln (1+$ Innotations $)$ & $0.675^{* * *}$ & $0.154 * * *$ & $0.564 * * *$ & $0.554 * * *$ & $0.175 * * *$ & $0.462 * * *$ \\
\hline & $(0.000)$ & $(0.000)$ & $(0.000)$ & $(0.000)$ & $(0.000)$ & $(0.000)$ \\
\hline Control variables & Yes & Yes & Yes & Yes & Yes & Yes \\
\hline Firm dummy & Yes & Yes & Yes & Yes & Yes & Yes \\
\hline Year dummy & Yes & Yes & Yes & Yes & Yes & Yes \\
\hline Observations & 17491 & 17491 & 17491 & 19938 & 19938 & 19938 \\
\hline P-value for AR(4) Test & & & & 0.190 & 0.086 & 0.169 \\
\hline P-value for Hansen Test & & & & 0.954 & 0.675 & 0.924 \\
\hline
\end{tabular}

This table estimates the effect of a firm's original innovations on the extent of its subsequent diversification. The model is as follows.

$$
D I V_{i, t}=\lambda \cdot I N N O V_{i, t-1}+X_{i, t-1} \cdot \Psi+\text { Firm_dummies }+ \text { Year_dummies }+\varepsilon_{i, t},
$$

where subscripts $i$ and $t$ refer to firm and year, respectively. The dependent variable, $D I V_{i, t}$ measures the extent of firm i's diversification in year $t$. We use the segment count as the proxy for $D I V_{i, t}$. The segment count of a firm is the number of its business segments at the 4-digit SIC level. To mitigate the endogeneity problem, all the independent variables are lagged by one year. The variable of interest, $I N N O V_{i, t-1}$ measures the innovations that firm $i$ has 
accumulated up to year $t-1 . X_{i, t-1}$ is a vector of one-year lagged firm characteristics as defined in the Appendix. Firm dummies and year dummies are included. Columns (1) to (3) of panel A presents the estimation results by using three different measures, $\ln (1+$ Patents $), \ln (1+$ Qcitation-Weighted Patents $)$ and $\ln (1+$ Tcitations-Weighted Patents), to proxy INNOV $V_{i, t-1}$, respectively. Columns (4) to (6) repeat the regressions of columns (1) to (3) by using the state R\&D tax credit as the instrument for $I N N O V_{i, t-1}$. We then time difference the above equation to obtain $\Delta D I V_{i, t}=\lambda \cdot \Delta I N N O V_{i, t-1}+\Delta X_{i, t-1} \cdot \Psi+$ Year $_{-}$Dummies $+\Delta \varepsilon_{i, t}$,

where firm dummies are removed by time differencing. Columns (1) to (3) of panel B estimate this model by using $I N N O V_{i, t-4}$ as the instrument for $\triangle I N N O V_{i, t-1}$. Columns (4) to (6) present the difference-GMM estimation results. Again, INNOV $V_{i, t-4}$ is used as the instrument for $\triangle I N N O V_{i, t-1}$. To save space, panel B does not report coefficients on control variables. For all estimations, robust standard errors clustered at the firm level are estimated. P-values are reported in the parentheses. ${ }^{*}, * *$, and $* * *$ indicate significance at $10 \%, 5 \%$ and $1 \%$, respectively. 
Table 3

The effect of innovation-relatedness on the direction of diversification.

Panel A. Summary statistics

\begin{tabular}{lcccccc}
\hline & \multicolumn{3}{c}{$\begin{array}{c}\text { Observations with } E N T R Y_{i, c, t}=0 \\
(N=97404)\end{array}$} & \multicolumn{2}{c}{$\begin{array}{c}\text { Observations with } E N T R Y_{i, c, t}=1 \\
(N=2411)\end{array}$} \\
Variable & Mean & $\begin{array}{c}\text { Median } \\
\text { Std. Dev. }\end{array}$ & Mean & Median & Std. Dev. \\
\hline Industry entry dummy & 0.00 & 0.00 & 0.00 & 1.00 & 1.00 & 0.00 \\
Related Patents & 0.13 & 0.00 & 0.49 & 0.49 & 0.00 & 0.95 \\
Related Patents\% & 0.00 & 0.00 & 0.02 & 0.03 & 0.00 & 0.06 \\
Related Qcitations & 0.30 & 0.00 & 1.01 & 1.08 & 0.00 & 1.86 \\
Related Qcitations\% & 0.00 & 0.00 & 0.02 & 0.03 & 0.00 & 0.06 \\
Related Tcitations & 0.13 & 0.00 & 0.49 & 0.49 & 0.00 & 0.98 \\
Related Tcitations\% & 0.00 & 0.00 & 0.02 & 0.03 & 0.00 & 0.06 \\
\hline
\end{tabular}

Panel B. Estimations results for the full sample

\begin{tabular}{lcccccc}
\hline & \multicolumn{5}{c}{ Dependent variable: Industry entry dummy } \\
\cline { 2 - 7 } Innovations are measured by & \multicolumn{5}{c}{ Sumple with Patent count $>0$} \\
\cline { 2 - 7 } & Patents & Qcitations & Tcitations & Patents & Qcitations & Tcitations \\
\cline { 2 - 7 } & $(1)$ & $(2)$ & $(3)$ & $(4)$ & $(5)$ & $(6)$ \\
\hline $\ln (1+$ Related-innovations) & $0.015^{* * *}$ & $0.005^{* * *}$ & $0.016^{* * * *}$ & $0.015^{* * *}$ & $0.005^{* * *}$ & $0.016^{* * *}$ \\
& $(0.000)$ & $(0.000)$ & $(0.000)$ & $(0.000)$ & $(0.000)$ & $(0.000)$ \\
Related-innovations\% & $1.070^{* * *}$ & $1.140^{* * *}$ & $1.132^{* * *}$ & $1.070^{* * *}$ & $1.140^{* * *}$ & $1.132^{* * *}$ \\
& $(0.000)$ & $(0.000)$ & $(0.000)$ & $(0.000)$ & $(0.000)$ & $(0.000)$ \\
Firm-year dummy & Yes & Yes & Yes & Yes & Yes & Yes \\
\hline Observations & 99815 & 99815 & 99815 & 89627 & 89627 & 89627 \\
Adjusted R-squared & 0.035 & 0.035 & 0.033 & 0.039 & 0.039 & 0.037 \\
\hline
\end{tabular}

Panel C. Estimation results for the sample excluding pairs with multiple entries

\begin{tabular}{lcccccc}
\hline & \multicolumn{5}{c}{ Dependent variable: Industry entry dummy } \\
\cline { 2 - 7 } Innovations are measured by & \multicolumn{5}{c}{ Sample with Patent count $>0$} \\
\cline { 2 - 7 } & Patents & Qcitations & Tcitations & Patents & Qcitations & Tcitations \\
\cline { 2 - 7 } & $(1)$ & $(2)$ & $(3)$ & $(4)$ & $(5)$ & $(6)$ \\
\hline $\ln (1+$ Related-innovations) & $0.011^{* * *}$ & $0.004^{* * *}$ & $0.011^{* * *}$ & $0.011^{* * *}$ & $0.004^{* * *}$ & $0.011^{* * *}$ \\
& $(0.000)$ & $(0.001)$ & $(0.000)$ & $(0.000)$ & $(0.001)$ & $(0.000)$ \\
Related-innovations\% & $1.037^{* * *}$ & $1.118^{* * *}$ & $1.125^{* * *}$ & $1.037^{* * *}$ & $1.118^{* * *}$ & $1.125^{* * *}$ \\
& $(0.000)$ & $(0.000)$ & $(0.000)$ & $(0.000)$ & $(0.000)$ & $(0.000)$ \\
Firm-year dummy & Yes & Yes & Yes & Yes & Yes & Yes \\
\hline Observations & 90205 & 90205 & 90205 & 80938 & 80938 & 80938 \\
Adjusted R-squared & 0.033 & 0.034 & 0.032 & 0.037 & 0.038 & 0.036 \\
\hline
\end{tabular}


This table estimates the likelihood of a firm's entry to a certain industry in a year, with one observation for the entered industry and multiple observations for other potential destination industries, conditional on that there is at least one entry for the firm-year. The fixed-effect linear probability model is as follows:

$$
\text { ENTRY }_{i, c, t}=\lambda \cdot R_{-} I N N O V_{i, c, t-1}+\text { Firm-year-dummies }+\varepsilon_{i, c, t},
$$

where subscripts $i, c$, and $t$ refer to firm, industry and year, respectively. The variable of interest is $R_{-} I N N O V_{i, c, t-1}$, which measures the extent that firm $i$ 's innovations in year $t-1$ are related to industry $c$. Destination industry dummies and pair dummies are included. A pair of observations refers to the observation of a firm-year's entry to a certain industry and multiple observations for other potential destination industries. The dependent variable, $E N T R Y_{i, c, t}$ is a dummy indicating whether firm $i$ enters industry $c$ in year $t$; it equals one if so, zero otherwise. An entry to one of 48 industries is confirmed when the following criteria are all satisfied: (1) the firm reports at least one business line within this industry in the year, but it is not so in the previous year; (2) this industry should not be reported by the firm two years ago if related information is available; (3) this industry should not be reported three years ago if related information is available. By these criteria, we end up with 2,411 entry counts within the examination period. Panel A presents the summary statistics of the sample pairs. To compare the difference between firm-year-industries without an entry $\left(E N T R Y_{i, c, t}=0\right)$ and those with an entry $\left(E N T R Y_{i, c, t}=1\right)$, we divide the sample into these two groups and report their summary characteristics, respectively. Columns (1) to (3) of panel B present the estimation results with the full sample by using three pairs of innovation relatedness measures to proxy $R_{-} I N N O V_{i, c, t-1}$, respectively. Columns (4) to (6) repeat the regressions of columns (1) to (3) by restricting the sample to those pairs with Patents greater than zero. Panel C repeats the regressions of panel B with the exclusion of pairs in which the firm-year has multiple entries. Robust standard errors clustered at the firm-year level are estimated. Pvalues are reported in the parentheses. $*, * *$, and $* * *$ indicate significance at $10 \%, 5 \%$ and $1 \%$, respectively. 
Table 4

The effect of innovation-relatedness on Tobin's Q.

Panel A. Summary statistics

\begin{tabular}{lllllll}
\hline & \multicolumn{3}{c}{ Tobin's Q $\geq$ median Tobin's Q } & \multicolumn{3}{c}{ Tobin's Q<median Tobin's Q } \\
& \multicolumn{3}{c}{$(N=800)$} & & \multicolumn{3}{c}{$(N=801)$} \\
\cline { 2 - 7 } Variable & Mean & Median & Std. Dev. & Mean & Median & Std. Dev. \\
\hline Tobin's Q & 1.33 & 1.02 & 0.83 & 0.36 & 0.38 & 0.18 \\
Related Patents \% & 0.08 & 0.00 & 0.19 & 0.06 & 0.00 & 0.15 \\
$\ln (1+$ Patents) & 1.64 & 0.69 & 2.04 & 1.67 & 0.97 & 1.98 \\
Related Qcitations \% & 0.09 & 0.00 & 0.21 & 0.07 & 0.00 & 0.16 \\
$\ln (1+$ Qcitations) & 2.95 & 2.46 & 3.08 & 2.91 & 2.78 & 2.91 \\
Related Tcitations \% & 0.08 & 0.00 & 0.21 & 0.06 & 0.00 & 0.16 \\
$\ln (1+$ Tcitations) & 1.62 & 0.49 & 2.09 & 1.45 & 0.42 & 1.91 \\
Diversification dummy & 0.53 & 1.00 & 0.50 & 0.69 & 1.00 & 0.46 \\
ln(Assets) & 4.98 & 4.70 & 2.10 & 5.03 & 4.82 & 1.89 \\
EBIT/Sales & 0.06 & 0.09 & 0.16 & 0.04 & 0.06 & 0.10 \\
Leverage & 0.53 & 0.51 & 0.22 & 0.55 & 0.55 & 0.18 \\
CAPEX/Sales & 0.09 & 0.05 & 0.11 & 0.05 & 0.04 & 0.06 \\
Sales growth (prior year) & 0.25 & 0.12 & 0.53 & 0.09 & 0.05 & 0.35 \\
\hline
\end{tabular}

Panel B. Estimation results for the full sample

\begin{tabular}{lcccccc}
\hline & \multicolumn{5}{c}{ Dependent variable: Tobin's Q } \\
\cline { 2 - 7 } Innovations are measured by & \multicolumn{5}{c}{ Full sample } & \multicolumn{3}{c}{ Sample with Patent count>0 } \\
\cline { 2 - 7 } & Patents & Qcitations & Tcitations & Patents & Qcitations & Tcitations \\
\cline { 2 - 7 } & $(1)$ & $(2)$ & $(3)$ & $(4)$ & $(5)$ & $(6)$ \\
\hline Related-Innovations\% & $0.251^{*}$ & $0.277^{* *}$ & $0.274^{*}$ & $0.315^{* *}$ & $0.323^{* *}$ & $0.337^{* *}$ \\
& $(0.100)$ & $(0.047)$ & $(0.064)$ & $(0.040)$ & $(0.021)$ & $(0.023)$ \\
ln(1+Innovations) & $0.020^{*}$ & 0.012 & $0.024^{* *}$ & $0.024^{* *}$ & $0.018^{* *}$ & $0.030^{* *}$ \\
& $(0.071)$ & $(0.130)$ & $(0.036)$ & $(0.041)$ & $(0.036)$ & $(0.014)$ \\
Diversification dummy & $-0.244^{* * *}$ & $-0.241^{* * *}$ & $-0.241^{* * *}$ & $-0.280^{* * *}$ & $-0.278^{* * *}$ & $-0.277^{* * *}$ \\
& $(0.000)$ & $(0.000)$ & $(0.000)$ & $(0.000)$ & $(0.000)$ & $(0.000)$ \\
ln(Assets) & $-0.021^{*}$ & -0.019 & $-0.023^{*}$ & -0.012 & -0.012 & -0.015 \\
& $(0.094)$ & $(0.113)$ & $(0.057)$ & $(0.358)$ & $(0.345)$ & $(0.244)$ \\
EBIT/Sales & 0.322 & 0.316 & 0.328 & $0.404^{*}$ & $0.402^{*}$ & $0.413^{*}$ \\
& $(0.187)$ & $(0.193)$ & $(0.176)$ & $(0.094)$ & $(0.092)$ & $(0.084)$ \\
Leverage & $-0.291^{* * *}$ & $-0.290^{* * *}$ & $-0.287^{* * *}$ & $-0.272^{* * *}$ & $-0.264^{* *}$ & $-0.266^{* *}$ \\
& $(0.007)$ & $(0.008)$ & $(0.008)$ & $(0.009)$ & $(0.012)$ & $(0.011)$ \\
CAPEX/Sales & $1.295^{* * *}$ & $1.280^{* * *}$ & $1.298^{* * *}$ & $1.249^{* * *}$ & $1.237^{* * *}$ & $1.255^{* * *}$ \\
& $(0.000)$ & $(0.000)$ & $(0.000)$ & $(0.000)$ & $(0.000)$ & $(0.000)$ \\
Sales growth (prior year) & $0.232^{* * *}$ & $0.231^{* * *}$ & $0.233^{* * *}$ & $0.182^{* * *}$ & $0.181^{* * *}$ & $0.183^{* * *}$ \\
& $(0.000)$ & $(0.000)$ & $(0.000)$ & $(0.000)$ & $(0.000)$ & $(0.000)$ \\
Year dummy & Yes & Yes & Yes & Yes & Yes & Yes \\
\hline Observations & 1601 & 1601 & 1601 & 1441 & 1441 & 1441 \\
Adjusted R-squared & 0.163 & 0.165 & 0.165 & 0.169 & 0.172 & 0.173 \\
\hline
\end{tabular}


Panel C. Estimation results for the sample excluding firm-years with multiple entries

\begin{tabular}{lcccccc}
\hline & \multicolumn{5}{c}{ Dependent variable: Tobin's Q } \\
\cline { 2 - 7 } Innovations are measured by & \multicolumn{5}{c}{ Full sample } & \multicolumn{4}{c}{ Sample with Patent count>0 } \\
\cline { 2 - 7 } & Patents & Qcitations & Tcitations & Patents & Qcitations & Tcitations \\
\cline { 2 - 7 } & $(1)$ & $(2)$ & $(3)$ & $(4)$ & $(5)$ & $(6)$ \\
\hline Related-Innovations\% & 0.232 & $0.270^{*}$ & $0.266^{*}$ & $0.292^{*}$ & $0.314^{* *}$ & $0.326^{* *}$ \\
& $(0.141)$ & $(0.058)$ & $(0.079)$ & $(0.066)$ & $(0.029)$ & $(0.032)$ \\
$\ln (1+$ Innovations) & 0.017 & 0.009 & $0.021^{*}$ & $0.021^{*}$ & $0.015^{*}$ & $0.026^{* *}$ \\
& $(0.137)$ & $(0.244)$ & $(0.088)$ & $(0.091)$ & $(0.091)$ & $(0.043)$ \\
Diversification dummy & $-0.246^{* * *}$ & $-0.243^{* * *}$ & $-0.243^{* * *}$ & $-0.280^{* * *}$ & $-0.277^{* * *}$ & $-0.277^{* * *}$ \\
& $(0.000)$ & $(0.000)$ & $(0.000)$ & $(0.000)$ & $(0.000)$ & $(0.000)$ \\
ln(Assets) & -0.015 & -0.013 & -0.017 & -0.007 & -0.007 & -0.010 \\
& $(0.264)$ & $(0.314)$ & $(0.194)$ & $(0.605)$ & $(0.606)$ & $(0.460)$ \\
EBIT/Sales & 0.348 & 0.344 & 0.357 & $0.465^{*}$ & $0.464^{*}$ & $0.476^{*}$ \\
& $(0.170)$ & $(0.174)$ & $(0.159)$ & $(0.065)$ & $(0.064)$ & $(0.058)$ \\
Leverage & $-0.293^{* *}$ & $-0.291^{* *}$ & $-0.287 * *$ & $-0.292^{* * *}$ & $-0.284^{* *}$ & $-0.284^{* *}$ \\
& $(0.011)$ & $(0.012)$ & $(0.012)$ & $(0.009)$ & $(0.011)$ & $(0.010)$ \\
CAPEX/Sales & $1.329^{* * *}$ & $1.312^{* * *}$ & $1.331^{* * *}$ & $1.348^{* * *}$ & $1.335^{* * *}$ & $1.352^{* * *}$ \\
& $(0.000)$ & $(0.000)$ & $(0.000)$ & $(0.000)$ & $(0.000)$ & $(0.000)$ \\
Sales growth (prior year) & $0.252^{* * *}$ & $0.251^{* * *}$ & $0.253^{* * *}$ & $0.200^{* * *}$ & $0.200^{* * *}$ & $0.201^{* * *}$ \\
& $(0.000)$ & $(0.000)$ & $(0.000)$ & $(0.000)$ & $(0.000)$ & $(0.000)$ \\
Year dummy & Yes & Yes & Yes & Yes & Yes & Yes \\
\hline Observations & 1448 & 1448 & 1448 & 1305 & 1305 & 1305 \\
Adjusted R-squared & 0.165 & 0.167 & 0.167 & 0.171 & 0.175 & 0.175 \\
\hline
\end{tabular}

This table examines how the innovation relatedness to an industry affects the growth rate of a firm's market-to-book ratio, conditional on that the firm diversifies into the industry. The model is as follows.

$$
\begin{aligned}
& Q_{i, t}=\beta_{0}+\beta_{1} \cdot R_{-} I N N O V_{i, c, t-1}+\beta_{2} \cdot I N N O V_{i, t-1}+\beta_{3} \cdot D I V_{-} D U M_{i, t-1}+\beta_{4} \cdot \operatorname{Ln}(\text { Assets })_{i, t-1} \\
& +\beta_{5} \cdot(\text { EBIT } / \text { Sales })_{i, t-1}+\beta_{6} \cdot \text { Leverage }_{i, t-1}+\beta_{7} \cdot(\text { CAPEX / Sales })_{i, t-1} \\
& +\beta_{8} \cdot \text { Sales_Growth }{ }_{i, t-1}+\text { Year_dummies }+\varepsilon_{i, t}
\end{aligned}
$$

where: $Q_{i, t}=$ firm $i$ 's Tobin's $\mathrm{Q}$ in year-end $t, c$ is the industry that firm $i$ enters in year $t$. Year dummies are included. INNOV $V_{i, t-1}$ measures the innovations that firm $i$ has accumulated up to year $t-1 . D I V_{-} D U M_{i, t-1}$ is the diversification dummy, indicating whether a firm is diversified or not; it equals one if diversified, and zero otherwise. A firm is defined as diversified in a given year if it has multiple segments at the 4-digit SIC level. Since we do not know exactly which entry is innovation related, we use $R_{-} I N N O V_{i, c, t-1}$ as a proxy. $R_{-} I N N O V_{i, c, t-1}$ measures the extent that firm $i$ 's innovations in year $t-1$ are related to industry $c$. The rest control variables are defined in the Appendix. With the inclusion of new controls, we end up with 1,601 valid firm-years with at least one entry. Panel A presents the summary statistics of these firm-years. To compare the difference between firm-years with faster and slower market-to-book ratio growth, we divide the sample into two groups by the median value of the market-to-book ratio growth rate, and report their summary characteristics, respectively. Columns (1) to (3) of panel B presents the estimation results with the full sample by using Related Patents\%, Related Qcitations\% and Related Tcitations\% to measure $R_{-} I N N O V_{i, c, t-1}$, respectively. In columns (4) to (6) of panel B we restrict the sample to firm-years with Patents greater than zero and rerun the regressions of columns (1) to (3). In panel C, we delete firm-years with multiple entries and rerun the regressions of panel B. Robust standard errors clustered at the firm level are estimated. P-values are reported in the parentheses. *, **, and *** indicate significance at $10 \%, 5 \%$ and $1 \%$, respectively. 


\begin{tabular}{|c|c|}
\hline \multicolumn{2}{|l|}{$\begin{array}{l}\text { Appendix } \\
\text { Variable definitions. }\end{array}$} \\
\hline \multicolumn{2}{|l|}{ Innovation Measures } \\
\hline Patents & $\begin{array}{l}\text { The sum of the number of awarded patents that the firm applies for in each year up } \\
\text { to a given year. An annual depreciation rate of } 15 \% \text { is adopted when summing up. }\end{array}$ \\
\hline Qcitation-Weighted Patents & $\begin{array}{l}\text { The sum of the Qcitation-weighted number of awarded patents that the firm } \\
\text { applies for in each year up to a given year. An annual depreciation rate of } 15 \% \text { is } \\
\text { adopted when summing-up. For each patent, the number of citations received each } \\
\text { year up to } 2006 \text { is multiplied by the weighting index from Hall, Jaffe and } \\
\text { Trajtenberg ( } 2001 \text {; henceforth HJT) to correct the truncation bias. }\end{array}$ \\
\hline Tcitation-Weighted Patents & $\begin{array}{l}\text { The sum of the Tcitation-weighted number of awarded patents that the firm applies } \\
\text { for in each year up to a given year. We follow Hirshleifer, Low and Teoh (2012) } \\
\text { and scale each patent's citations by the average citation count of all patents in the } \\
\text { same technology class and year. For each patent, we multiply the number of scaled } \\
\text { citations received each year by the HJT weights. }\end{array}$ \\
\hline \multicolumn{2}{|c|}{ Innovation-Relatedness Measures } \\
\hline Related Patents & $\begin{array}{l}\text { We determine whether a patent is related to industry } c \text { (one of the } 48 \text { industries) in } \\
\text { the following way. Each patent belongs to a USPC subclass. When a patent is } \\
\text { under a USPC subclass that is assigned only to industry } c \text {, it is counted as one } \\
\text { patent related to industry } c \text {. If a patent under a USPC subclass is matched to } \\
\text { multiple industries, the patent is evenly distributed to these industries. We then } \\
\text { aggregate the number of the patents related to industry } c \text { each year, and sum them } \\
\text { up till year } t-1 \text { by assuming an annual depreciation rate of } 15 \% \text { to get Related } \\
\text { Patents to industry } c \text {. }\end{array}$ \\
\hline Related Patents\% & The ratio of Related Patents over Patents. \\
\hline Related Qcitations & The Qcitation-weighted Related Patents. \\
\hline Related Qcitations\% & The ratio of Related Qcitations over Qcitation-Weighted Patents. \\
\hline Related Tcitations & The Tcitation-weighted Related Patents. \\
\hline Related Tcitations\% & The ratio of Related Tcitations over Tcitation-Weighted Patents. \\
\hline \multicolumn{2}{|l|}{ Firm Characteristics } \\
\hline Segment Count & The number of a firm's business segments at the 4-digit SIC level. \\
\hline Diversification Dummy & $\begin{array}{l}\text { A dummy variable that equals one if it is diversified, and zero otherwise. A firm is } \\
\text { defined as diversified in a given year if it has multiple segments at the 4-digit SIC } \\
\text { level. }\end{array}$ \\
\hline Sales-Based Segment HHI & $\begin{array}{l}\text { The sum of squared sales shares of all segments defined at the 4-digit SIC level. } \\
\text { The sales share of a segment is defined as its sales over the total sales of the firm. } \\
\text { A firm may have multiple segments at the same 4-digit SIC level. In this case, the } \\
\text { sales of these segments are aggregated first before calculating the sales share. }\end{array}$ \\
\hline Tobin's $Q$ & $\begin{array}{l}\text { (Market value of equity }+ \text { Liquidating value of preferred stock+Short-term } \\
\text { liabilities }- \text { short term assets+book value of long-term debt)/Total assets }\end{array}$ \\
\hline $\ln ($ Assets $)$ & The natural logarithm of total assets. \\
\hline EBIT/Sales & The ratio of earnings before interest and taxes (EBIT) over sales revenues. \\
\hline CAPEX/Sales & The ratio of capital expenditures over sales revenues. \\
\hline Leverage & The ratio of total debts over total assets. \\
\hline Sales Growth & The growth rate of sales. \\
\hline
\end{tabular}

